\title{
Pembentukan First Responder (FR) Berbasis Internet of Things Sebagai Upaya Peningkatan Kapasitas Tenaga Kesehatan Terhadap Darurat Bencana di Wilayah Kerja Puskesmas Tangerang, Banten
}

\author{
Taryudi \\ Univeristas Negeri Jakarta \\ e-mail: taryud@yahoo.com
}

\begin{abstract}
Abstrak
Tangerang merupakan wilayah yang rentan terhadap bencana seperti banjir tahunan atau kebocoran bahan berbahaya dari limbah industri. Program yang selama ini ada hanya sebatas pada perbaikan infrasktruktur dan kebijakan, belum ada program yang berorientasi pada peningkatan kapasitas tenaga kesehatan setempat sebagai front liner dalam kaitanya dengan penanganan gawat darurat bencana. Metode yang digunakan mengacu pada problem solving process dengan menganalisa meliputi input, proses, dan output. Input ini adalah karakteristik dan budaya masyarakat setempat yang harus menjadi dasar dalam mengembangkan program terutama pendekatan yang akan digunakan. Pembentukan komunitas tanggap bencana, dan pembentukan pos untuk First Reponder (FR) yang terintegrasi dengan puskesmas dan keluarahan setempat. Dari hasil pelaksanaan program didapatkan peningkatan pengetahuan dan keterampilan tenaga Kesehatan dalam penanngulangan bencana dan terbentuknya sebagai first responder yaitu orang yang bertanggung jawab dalam mempimpin kesiapsiagaan dan penanggulangan bencana. Program ini merupakan suatu pendekatan yang bebasis pemberdayaan tenaga Kesehatan dengan pemanfaatan aplikasi yang sudah tersedia untuk komunikasi yaitu media sosial dan reminder sistem.
\end{abstract}

Kata Kunci: First responder, bencana, tenaga Kesehatan, Internet of things

\begin{abstract}
Tangerang is an area prone to disasters such as annual flooding or leakage of hazardous materials from industrial waste. So far, the government's efforts have been carried out under the coordination of the West Java government by involving the police and BPPB in handling the disaster. There are very few disaster management programs that involve health service institutions as the first line in handling health problems including disasters. Then the existing programs are limited to improving infrastructure and policies, there is no program that is oriented towards increasing the capacity of local health workers as front liners in relation to handling disaster emergencies. The method that will be used refers to the problem solving process by analyzing it includes input, process, and output. This input is the characteristics and culture of the local community that must be the basis for developing the program, especially the approach to be used. These inputs include: demographic characteristics (age, gender, level of education, religion, ethnicity, socioeconomic). Then in the
\end{abstract}


process stage, the first one as an effort to increase the capacity of soft skills and hard skills, there will be counseling, training and coaching with the focus areas of disaster preparedness and management. Then, the formation of a disaster response community, and the establishment of a post for First Reponder (FR) in conjunction with community health centers and local families. Furthermore, a coaching program for the sustainability of the program through a collaborative evaluation and monitoring system between FT UNJ and Puskesmas Bakti Jaya Tangerang. From the results of program implementation. From the results of program implementation, it was found that increased knowledge and skills of health workers in disaster management and the formation of first responders, namely people who are responsible for leading disaster preparedness and management. This program is an approach based on the empowerment of health workers by utilizing existing applications for communication, namely social media and reminder systems.

Keywords: First responders, disaster, health personnel, Internet of things

\section{Pendahuluan}

Indonesia merupakan negara yang sangat rawan terhadap bencana alam (natural disaster) maupun bencana yang disebabakan karena ulah manusia yang tidak bertanggung jawab (man-made disaster) yang terletak pada persimpangan lempeng, daerah tropis dengan curah hujan yang tinggi, dan memiliki banyak gunung merapi yang aktif. Menurut Data Informasi Bencana Indonesia (DIBI)-BNPB pada tahun 2018 mencatat terdapat 2.572 kejadian bencana di Indonesia, yang terdiri dari angin puting beliung sebanyak 804 kejadian, banjir sebanyak 679 kejadian, longsor sebanyak 473 kejadian, kebakaran hutan dan lahan 370 kejadian, kekeringan 129 kejadian, letusan gunung api 58 kejadian, gelombang pasang atau abrasi 34 kejadian, gempa bumi 23 kejadian, gempa bumi diikuti tsunami 1 kejadian dan tsunami sebanyak 1 kejadian.

Dampak yang ditimbulkan dari bencana tersebut diantaranya adalah puluhan ribu infrastruktur dan fasilitas mengalami kerusakan. Sebanyak 150.513 rumah rusak berat, 39.815 rumah rusak sedang dan 129.837 rumah rusak ringan. Selain itu, juga terdapat kerusakan 1.736 unit fasilitas pendidikan, 857 fasilitas peribadatan dan 106 fasilitas kesehatan. Kemudian, bencana juga menyebabkan 10.333 .309 jiwa menderita dan mengungsi, 21.083 luka-luka, dan 4.814 meninggal atau hilang (BNPB, 2018). Sejalan dengan data diatas, BNPB mencatat 5 Provinsi yang paling sering dilanda bencana selama periode tahun 2016, Provinsi Jawa Barat menempati peringkat ketiga setelah Jawa Tengah dan Jawa Timur (BNPB, 2018).

Hampir semua kota besar di Indonesia berada di wilayah pesisir. Berbagai kegiatan mulai dari permukiman, perdagangan, transportasi, pengembangan industri dan berbagai sektor lainnya dijejalkan ke kawasan ini. Diperkirakan $60 \%$ populasi Indonesia dan $80 \%$ lokasi industri berada di wilayah pesisir. Pada tahun 1883, provinsi Banten khususnya pantai Barat telah dilanda tsunami (diperkirakan ketinggian tsunami mencapai 41 meter), yang disebabkan oleh letusan Gunung Krakatau dengan sekitar 36.000 orang meninggal. Potensi gempa bumi dan tsunami 
yang mengancam pantai barat Provinsi Banten cukup besar, dengan waktu tempuh gelombang tsunami 30-45 menit. Pada tahun 2018 daerah Banten kembali dilanda tsunami yang disebabkan oleh gelombang pasang abnormal karena bulan purnama dan tanah longsor yang terjadi di bawah laut setelah meletusnya bencana gunung berapi Anak Krakatau (Badan Nasional Penanggulangan Bencana, 2018). Selama ini upaya pemerintah yang dilakukan berfokus pada structural level dengan melibatkan pihak kepolisian dan BPPB dalam penanganan bencana tersebut. Kemudian program yang Selama ini ada hanya sebatas pada perbaikan infrasktruktur dan kebijakan, belum ada program yang berorientasi pada peningkatan kapasitas masyarakat setempat sebagai subjek dan potensial korban utama dalam kaitanya dengan penangananan gawat darurat bencana. Sedikit sekali program penanganan bencana yang melibatkan institusi pelayanan kesehatan sebagai lini pertama dalam penanganan masalah kesehatan termasuk bencana.

Kesiapan tenaga kesehatan dalam keadaan bencana dituntut harus mampu mengelola pelayanan sehari-hari, pelayanan korban akibat bencana, serta aktif membantu dalam penyelamatan nyawa korban bencana (Depkes RI. Pedoman Teknis Penanggulangan Krisis Kesehatan Akibat Bencana, 2007). Dalam dekade terakhir, ada upaya signifikan yang dilakukan oleh pemerintah Indonesia untuk memperluas dan meningkatkan standar penyediaan layanan kesehatan. Namun, terlepas dari upaya ini, sistem kesehatan masih belum berkembang dengan baik. Disamping meningkatnya peran sektor swasta, akan tetapi pertumbuhan itu bukan sebagai investasi untuk meningkatkan pelayanan kesehatan masyarakat tetapi mengarah pada pembangunan infrastruktur penunjang ekonomi (Kementrian Keuangan, 2017). Dilaporkan bahwa layanan kesehatan hanya tercakup $67,0 \%$ dari populasi, sebagian besar di daerah perkotaan, dan hanya 35,0\% dari masyarakat pedesaan (Kementrian Kesehatan, 2017). Keterbatasan pelayanan kesehatan dalam penanganan bencana menjadi salah satu penyebab meningkatnya angka kematian dan kesakitan (bnpb.go.id). kesiapan tenaga kesehatan untuk menanggapi peristiwa bencana dipengaruhi oleh kompetensi yang mereka miliki, kekhawatiran tentang keselamatan pribadi dan kepedulian terhadap keluarga mereka (Melnikov et al., 2014). Karaktertisk demografik seperti jenis kelamin tenaga kesehatanya ternyata juga dilaporkan berhubungan dengan kesiapan dalam beresponse terhadap bencana. Satu survei terhadap petugas layanan kesehatan menemukan bahwa wanita kurang bersedia melapor ketika terjadi bencana, memiliki stress dan tekanan psikologis yang lebih tinggi dari pada laki-laki (Pflanz, 2006; Queshi, 2005).

Internet of things (IoT) saat ini menjadi trending topik di era industri 4.0 dan membawa peluang besar terhadap perkembangan teknologi dan human development goal. IoT didefinisikan sebagai integrasi semua perangkat yang terhubung ke jaringan, yang dapat dikelola dari web sehingga mampu memberikan informasi secara real time dan memungkinkan interaksi dengan pengguna.

Tujuan dari program ini adalah untuk mengevaluasi efektifitas dari Program pembentukan First Reposnder (FR) merupakan bagian dari konsep pre- hospital care 
yang dikembangkan berbasis community emprowerment terhadap pengetahuan, sikap, dan perilaku terhadap darurat bencana di Wilayah Kerja Puskesmas Tangerang, Banten. Kegiatan ini bermanfaat untuk meningkatakan kewaspadaan dan kesiapan tenaga kesehaatan dalam menghadapi darurat bencana yang mungkin terjadi kapanpun.

\section{Metode}

Program pembentukan First Reposnder (FR) merupakan bagian dari konsep prehospital care yang dikembangkan berbasis community emprowerment. Program ini dikembangkan melalui tiga tahap, yaitu:

1. Proses perizinan dan birokrasi, proses pemberdayaan masyarakat melalui penyuluhan, pelatiha, dan pembinaan.

2. Program inti yang berisi: Pembentukan "komunitas tanggap bencana" dengan program kerja yang sudah disepakati dan pembentukan model dan pos untuk first reposnder (FR).

3. Program pembinaan untuk menjaga keberlangsungan program yang akan dilakukan melalui in service training.

Secara umum metode yang akan digunakan adalah:

1. Focus group discussion (FGD) dengan tujuan menggali permasalahan dan sumber daya manuasia yang ada diwilayah tersebut yang hasil dari FGD akan digunakan untuk mengembangkan program supaya bener-bener bisa sesuai dengan kebutuhan dan mencapai target yang rasional.

2. Peningkatan kapasitas tenaga kesehatan secara umum melalui pendidikan kesehatan, pelatihan, dan pembinaan mengenai disaster preparedness and management

3. Pembentukan "perawat tanggap bencana" dengan program jangka pendek yang sudah dibuat serta indikator capaian yang disepakati. Pembentukan "perawat tanggap bencana" akan dilakukan melalui musyawarah yang melibatkan kader dan masyarakat yang peduli serta sukarela dan di deklarasikan secara umum untuk sosialisisnya.

4. Pembentukan pos dan model First Reposnder (FR) berbasis IoT ini merupakan sebuah model dan sistem serta bentuk ril dari program ini. Pos akan didirikan terintegrasi dengan kelurahan dibawah koordinasi pemerintahan setempat dan puskesmas. Model merupakan sebuah sistem kerja First Reposnder (FR) dimasyarakat.

Program pembinaan akan dilakukan dengan metode inservice training untuk upgrade pengetahuan baru dan memonitor keberlanjutan program. 


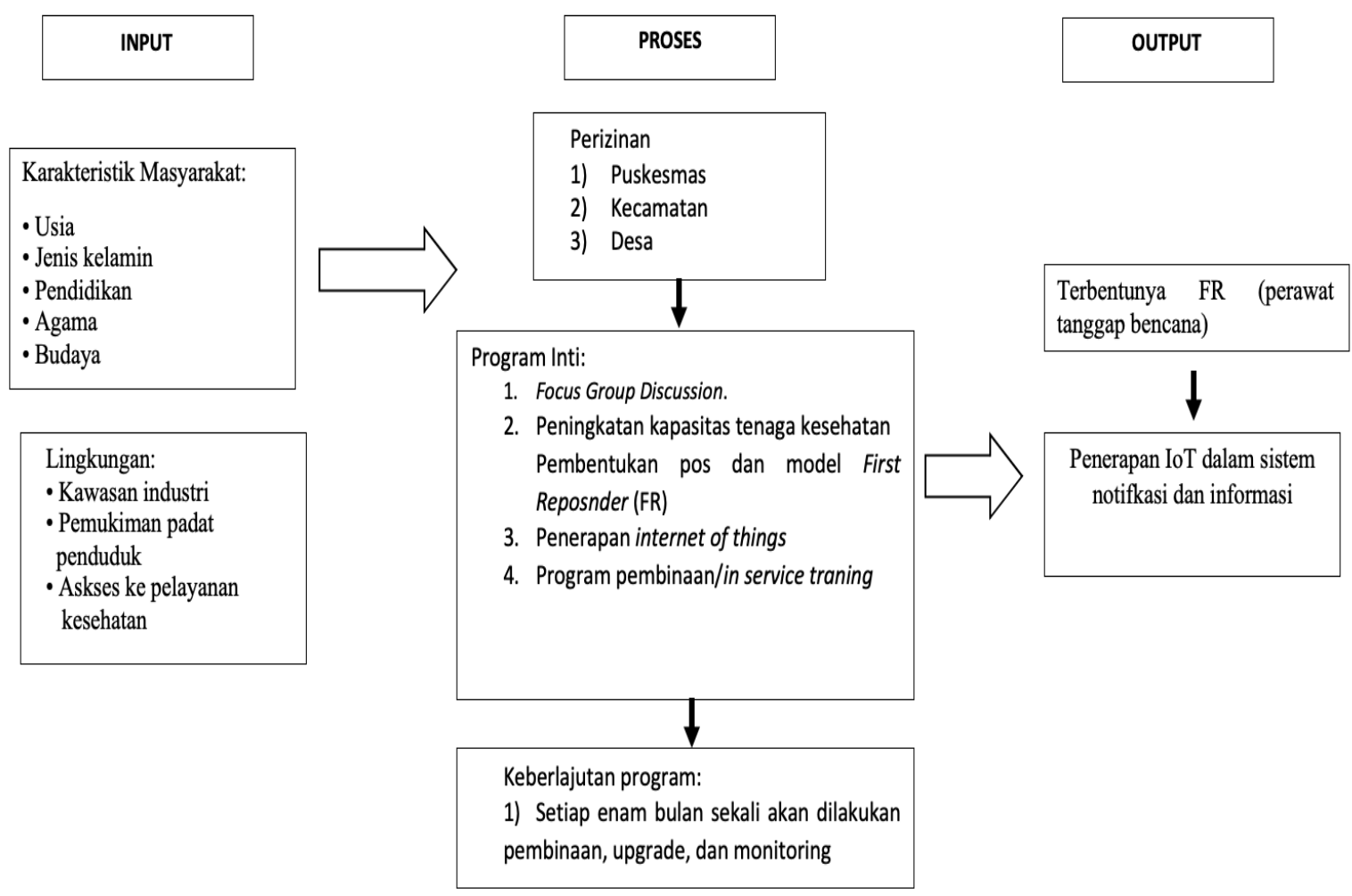

Gambar 1. Metode pelaksanaan program

\section{Hasil dan Pembahasan}

Tujuan dari program ini adalah untuk membentuk First Responder (FR) Berbasis Internet of Things Sebagai Upaya Peningkatan Kapasitas Tenaga Kesehatan Terhadap Darurat Bencana di Wilayah Kerja Puskesmas Tangerang, Banten. Sebanyak 30 tenaga kesehatan setuju untuk berpartisipasi dalam penelitian ini. Sebagian besar siswa $(80 \%)$ adalah perempuan dengan usia rata-rata $32,54(\mathrm{SD}=2,76)$ Sumber informasi yang sering digunakan oleh tenaga kesehatan adalah sebagian besar $(86.7 \%)$ melalui internet. Berdasarkan hasil paired $\mathrm{t}$ test didapatkan bahwa program ini efektif dalam meningkatan pengetahuan, sikap, dan perilaku tenaga kesehatan terhadap penanggulangan bencana ( $p$ value $<0.001$, dengan nilai beda sebesar 7,13 untuk pengatahuan, 5,02 untuk sikap, dan 4,24 untuk perilaku (Tabel 1).

Tabel 1. Pengetahuan, sikap, dan perilaku tenaga kesehatan setelah pelaksanaan program $(n=30)$

\begin{tabular}{|c|c|c|c|c|}
\hline & $\begin{array}{c}\text { Pre-test } \\
\text { Mean (SD) }\end{array}$ & $\begin{array}{c}\text { Post-test } \\
\text { Mean (SD) }\end{array}$ & p-values & Nilai Beda \\
\hline Pengetahuan & 13,31 (SD:1,95) & $20,96(\mathrm{SD}: 9,12)$ & 0,001 & 7,13 \\
\hline Sikap & 35,45 (SD:2,62) & $40,52(\mathrm{SD}: 5,45)$ & 0,001 & 5,02 \\
\hline Perilaku & $17,72(\mathrm{SD}: 2,5)$ & 21,18 (SD: 7,32) & 0,04 & 4,24 \\
\hline
\end{tabular}




\section{Pembahasan}

Tenaga kesehatan merupakan garda terdepan dalam penanganan bencana. Peran penting perawat selama bencana ditekankan dalam kebijakan kesehatan yang bertujuan mempersiapkan perawat secara memadai untuk respons bencana secara lokal dan internasional. Terutama, kerangka Kompetensi Keperawatan Bencana yang diterbitkan oleh International Council of Nurses (ICN) pada tahun 2009 menguraikan 10 domain kompetensi untuk perawat yang menanggapi bencana (ICN 2009). Kesiapsiagaan tenaga kesehatan dalam menghadapi bencana sangat dipengaruhi oleh beberapa faktor salah satunya adalah pengetahuan terhadap risiko bencana, sikap terhadap risiko bencana. Kurangnya pengetahuan dan kesiapan dapat mempengaruhi kinerja yang buruk ketika memberikan penanggulangan bencana. Kegiatan kesiapsiagaan hendaknya didasarkan kepada pengetahuan tentang potensial dampak bahaya bencana dalam kesehatan dan keselamatan, pengetahuan merupakan faktor utama dan menjadi kunci untuk kesiapsiagaan.

Pengetahuan yang dimiliki biasanya dapat mempengaruhi sikap dan kepedulian untuk siapsiaga dalam mengantisipasi bencana. Sikap sangat mempengaruhi perawat dalam penanggulangan bencana terutama ketika menjadi petugas penanggulangan bencana, selain itu sikap dapat mendukung kemauan perawat dalam meningkatkan pengetahuan. Sikap positif dapat menunjukkan kesiapan petugas kesehatan dalam belajar mengenai manajemen bencana dan berkeinginan untuk bersiap dalam menghadapi bencana.

Kesiapsiagaan adalah serangkaian kegiatan yang dilakukan untuk mengantisipasi bencana melalui pengorganisasian serta melalui langkah yang tepat guna dan berdaya guna. Kesiapsiagaan bencana adalah setiap aktivitas sebelum terjadinya bencana yang bertujuan untuk mengembangkan kapasitas operasional dan memfasilitasi respon yang efektif ketika terjadi suatu bencana. Kesiapsiagaan rumah sakit dalam keadaan bencana dituntut harus mampu mengelola pelayanan seharihari, pelayanan korban akibat bencana, serta aktif membantu dalam penyelamatan nyawa korban bencana. Pada situasi bencana rumah sakit dan fasilitas pelayanan kesehatan lainnya seperti puskesmas, harus aman, mudah diakses serta berfungsi dengan kapasitas maksimal untuk menyelamatkan korban dan harus tetap menyediakan pelayanan kesehatan sebagaimana seharusnya dan harus diorganisir dengan perencanaan rumah sakit dan fasilitas pelayanan kesehatan lainnya.

\section{Simpulan dan Rekomendasi}

Dari hasil pelaksanaan program pembentukan First Reposnder (FR) didapatkan peningkatan pengetahuan, sikap, dan keterampilan tenaga Kesehatan dalam penanggulangan bencana dan terbentuknya sebagai first responder yaitu orang yang bertanggung jawab dalam mempimpin kesiapsiagaan dan penanggulangan bencana. Program ini merupakan suatu pendekatan yang bebasis pemberdayaan tenaga Kesehatan dengan pemanfaatan aplikasi yang sudah tersedia untuk komunikasi yaitu media sosial dan reminder system. Sehingga program berikutnya perlu 
dikembangkan untuk meningakatkan keberlajutan program seperti melalui pengembangan yang terintegrasi dan menggunakan teknologi sebagai media penyampaian dan promosi.

\section{Daftar Pustaka}

BNPB 2018. “Data Informasi Bencana Indonesia”. (http://dibi.bnpb.go.id diakses 17 Februari 2020)

Iqbal, Donny. " Dana Terus Mengalir, Tetapi Banjir rancaekek Tetap Hadir". (www.mongabay.co.id 17 Februari 2020).

FT-UNJ. (2018). Panduan Pelaksanaan Penelitian dan Pengabdian kepada Masyarakat FT-UNJ 2018. Jakarta

Kemenkes RI. (2007). Pedoman Teknis Penanggulangan Krisis Kesehatan Akibat Bencana. Jakarta.

Kemenkes RI. (2016). Laporan Penanggulangan Krisis Kesehatan Akibat Banjir Bandang Di Kab. Garut Dan Tanah Longsor Di Kab . Sumedang. Jakarta. Retrieved from http:/ / www.pusatkrisis.kemkes.go.id/laporan-penanggulangan-krisiskesehatan-akibat-banjir-bandang-di-kab-garut-

Melnikov, S., Itzhaki, M., \& Kagan, I. (2014). Israeli Nurses' Intention to Report for Work in an Emergency, (1991), 134-142. https:/ / doi.org/10.1111/jnu.12056 